\title{
SEDIMENT OXYGEN CONSUMPTION AND HYDROGEN SULFIDE RELEASE IN HYPOXIC AREAS OF GAMAK BAY, KOREA
}

\author{
LEE, T. ${ }^{1}-$ KIM, H. C. ${ }^{2}-$ SON, Y. B. ${ }^{*}$ \\ ${ }^{1}$ Jeju Environmental Research Center, Korea Institute of Ocean Science \& Technology \\ Iljudong-ro 2670, Gujwa, Jeju 63349, Republic of Korea \\ ${ }^{2}$ Unit of Arctic Sea-Ice Prediction, Korea Polar Research Institute \\ Songdomirae-ro 26, Yeonsu-gu, Incheon 21990, Republic of Korea \\ (phone: +82-32-760-5335; fax: +82-32-760-5398) \\ *Corresponding author \\ e-mail: sonyb@kiost.ac.kr; phone: +82-64-798-6071; fax: +82-64-798-6085
}

(Received $7^{\text {th }}$ Nov 2018; accepted $4^{\text {th }}$ Feb 2019)

\begin{abstract}
This study investigated sediment oxygen consumption rates and geochemical characteristics using chamber experiments and geochemical analyses in the hypoxic area of Gamak Bay, Korea. The organic carbon contents of surface sediments in Gamak Bay were higher in the northern inner bay area, and dropped off toward the southern outer bay. The vertical profiles of calcium carbonate content in piston core sediments indicated that hypoxia has frequently occurred during the past century in the northern inner bay. Sediment chamber experiments were conducted in February, May, August, and November 2010 and 2011 in the hypoxic area of the bay. In the sediment incubation experiments at site $\mathrm{C} 3$ in the northern inner bay and site $\mathrm{C} 17$ in the southern outer bay, the sediment oxygen consumption rate ranged from $3.98-12.43 \mathrm{mmol} \mathrm{m}^{-2} \mathrm{~d}^{-1}$ and $3.28-8.18 \mathrm{mmol} \mathrm{m}^{-2} \mathrm{~d}^{-1}$, respectively. When the oxygen was completely depleted, hydrogen sulfide was released at 1.38 and $1.3 \mathrm{mmol} \mathrm{m}^{-2} \mathrm{~d}^{-1}$ at sites $\mathrm{C} 3$ and $\mathrm{C} 17$, respectively.
\end{abstract}

Keywords: hypoxia, ocean acidification, dissolved oxygen, sediment oxygen consumption rate, sediment incubation chamber

\section{Introduction}

Hypoxia occurs seasonally in coastal areas such as estuaries, coastal upwelling areas, and eutrophic waters due to the excessive input of nutrients from rivers. Hypoxic water masses have a dissolved oxygen (DO) concentration $\leq 2 \mathrm{mg} \mathrm{L}^{-1}$ due to biochemical factors, and are mainly seen throughout the world in highly productive waters and semienclosed bays, such as lakes and upwelling areas (Severdrup et al., 1972; Hanazato, 1997; Karim et al., 2002; Wu, 2002; Turner et al., 2005). When there is a large input of organic matter to the ocean bottom layer, and the flow of seawater between the surface and bottom layers is blocked due to stratification, an environment is created in which hypoxia can occur.

Hypoxia is known to occur in the coastal areas of many Asian countries (Wu, 1982; Hong, 1987; Jeng and Han, 1996; Lim et al., 2006). In Korea, hypoxia is reported to occur often in the summer season in connection with red tides (Cho, 1991; Kim, 1990). There is insufficient evidence supporting the occurrence of hypoxic water masses in Cheonsu Bay and Gamak Bay (GB), but these Bays are a focus of concern due to massive organism deaths (Shin, 1995). The depletion of oxygen in a water mass directly affects the respiration and physiological functions of fish and shellfish, as well as the species composition and abundance of benthic organism populations (Hong, 1987; Wu, 
2002; Karim et al., 2003). Bottom layer hypoxic water masses, which occur in coastal areas, not only directly damage benthic organisms, but can have various secondary effects on the coastal ecosystem. It is also known that the upwelling of hypoxic bottom layers can directly lead to organism deaths and cause the water to lose its selfpurification functions (Yoon, 1998; Karim et al., 2002).

DO in ocean sediment is consumed by organic matter decomposition, benthic organism respiration, and the oxidation of chemical species. Most DO is consumed by organic matter decomposition, but it is also consumed by nitrification reactions in the nitrogen cycle, the reoxidation of reduced manganese and iron species, and the oxidation of hydrogen sulfide (Lee et al., 2008, 2010). These reactions occur after most of the oxygen has been depleted. If the flow of seawater is disrupted, the reactions can show high abundance and rapidly lead to an anoxic environment. If the anoxic bottom layer environment persists, organic matter decomposition occurs in an anaerobic state and produces ammonia, hydrogen sulfide, and methane. This can limit the distribution and movement of benthic organisms (Yoon, 1998).

The GB is a semi-closed bay in the central part of the Korean peninsula's South Sea. It has an oval shape with a north-south length of $15 \mathrm{~km}$, an east-west length of $9 \mathrm{~km}$, and large and small islands located at its entrance, giving it an almost-closed form. The central area of the GB has a depth of 6-7 m, and the northern inner bay has a depth of 9-10 m. The seabed has a concave, basin-like topography (Fig. 1). The bay's sedimentary layer was deposited over the last 6,000 years in accordance with high water levels. The thickness of the sedimentary layer is $5-25 \mathrm{~m}$, being thickest in the central part of the bay and thinner toward the northern inner bay (Kim et al., 2014). The GB is surrounded by islands that strongly affect the conditions therein. Water from the open sea flows in through the bay entrance, and also from another source, Gwangyang Bay, causing different water masses to appear (Lee and Cho, 1990). Approximately $80 \%$ of the seawater flows in and out of the bay through its northern entrance, while $\sim 20 \%$ flows in and out through a narrow channel. Seawater from both sides meets in the middle of the bay (Lee and Chang, 1982). In summer, stratification occurs readily in water masses in the northern inner bay due to the increased temperature of the surface water and the inflow of freshwater. During flood tide and ebb tide, seawater flow only occurs within the surface layer. It is known that in the northern inner bay, which has a concave seabed, the bottom water is very stagnant (Lee and Cho, 1990).

Hydrogen sulfide is a toxic gas produced when sulfate-reducing bacteria reduce sulfur compounds to hydrogen sulfide in an anaerobic state. Hydrogen sulfide is easily oxidized, which results in the formation of sulfur precipitates. In anoxic environments, hydrogen sulfide is released within the water column and causes mass death of organisms (Milby and Baselt, 1999; Cuevasanta et al., 2017). Hydrogen sulfide is highly toxic and causes great harm to organisms at concentrations of $500 \mathrm{ppm}$ or more; above 1,000 ppm, it causes death (Guidotti, 1994).

The purpose of this study was to investigate the effect of sediment on the hypoxia occurring in GB in the summer of each year. We also investigated the phenomenon that can occur as the duration of hypoxia increases. This study used sediment chamber experiments to measure the oxygen consumed by sediments in regions of the GB where hypoxic water masses occur, to understand how oxygen consumption affects the formation of hypoxic water masses. This study also measured the hydrogen sulfide flux released from sediments during continual hypoxia. 


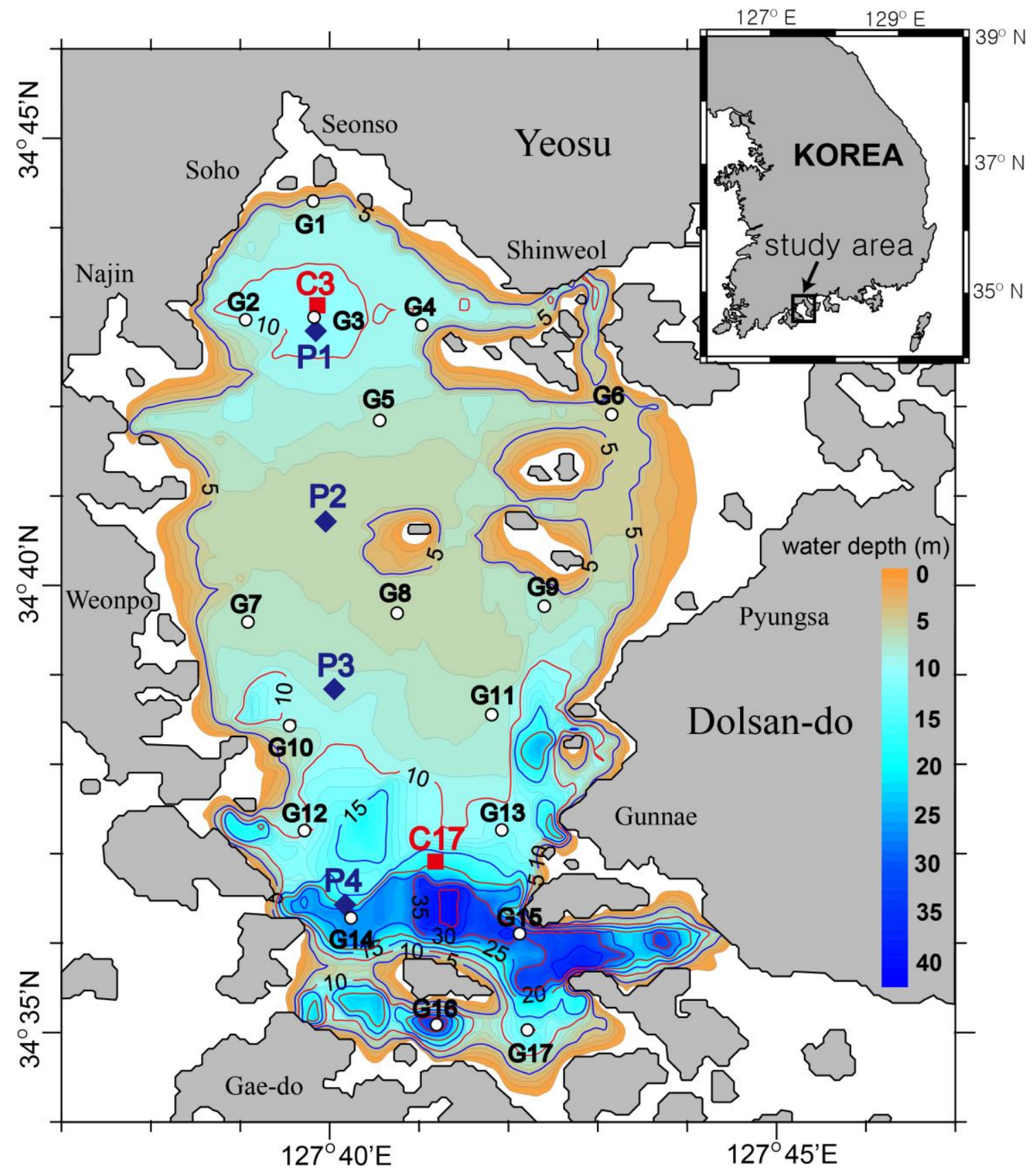

Figure 1. The locations of piston coring sites (P1-P4), grab sampling sites (G1-G17), and chamber experiment sampling sites (C3 and C17) in Gamak Bay, Korea. The solid lines are contours of water depth; water depth is in meters

\section{Materials and methods}

Surface layer sediments were collected for analysis at 17 sites (G1-G17) using a grab sampler. At 4 sites (P1-P4), a piston corer was used to collect core sediments. At 2 sites (C3 and C17), a box corer was used seasonally to collect sediments for incubation experiment (Fig. 1). In the bottom layer of site $\mathrm{C} 3$, a hypoxic water mass is formed every summer season. In the bottom layer of site $\mathrm{C} 17$, DO concentration is normally distributed. The incubation experiment samples were collected from 2 sites in May, 
August and November, 2010 and February, May, August and November, 2011, respectively.

The surface layer sediment was placed in a sample bag and placed in cold storage. In the laboratory, sediment samples were dried and powdered for geochemical analysis, and particle size analysis was also performed. The core sediment was cut in the laboratory, and subsampling was conducted at each measured depth. After pre-treatment of the surface layer and core sediments, the particle sizes were analyzed. The pretreatment consisted of a $10 \%$ hydrochloric acid $(\mathrm{HCl})$ solution, used to remove carbonates, and a $30 \%$ hydrogen peroxide $\left(\mathrm{H}_{2} \mathrm{O}_{2}\right)$ solution to remove organic matter. The pre-treated sediment samples were cleansed several times with distilled water, and a $4 \phi$ sieve was used to divide the sediment into particle sizes $>4 \phi$ and $<4 \phi$. The particle sizes of sediments $<4 \phi$ were analyzed with a particle size analyzer (Sedigraph 5100 ), and the proportion of sediment $>4 \phi$ was evaluated statistically (Folk, 1954). After the sediment samples were transported to the laboratory and dried, their weight was measured to assess their water contents. The dried sediment samples were powdered, and their total carbon and inorganic carbon contents were measured. The total carbon and nitrogen contents were analyzed using a CHNS elemental analyzer (Carlo-Erba), and the inorganic carbon content was analyzed using a coulometric carbon analyzer (UIC). The total organic carbon (TOC) content was calculated by subtracting the inorganic carbon content from the total carbon content. The calcium carbonate $\left(\mathrm{CaCO}_{3}\right)$ content was calculated by multiplying the inorganic carbon content by 8.33 .

After collecting sediment samples in a chamber, incubation experiments were performed in an environment similar to the field conditions in terms of temperature and light. Using a temperature-adjustable water bath, the chamber temperature was kept as similar as possible to that of the bottom water. A dark room with almost no natural light was created, so that exposure to light was minimal. Bottom water $(\sim 2 \mathrm{~L})$ collected sites C7 and C13 was carefully poured into the chamber containing the sediment samples to cause minimal disturbance to the sediment, and contact with the air was completely blocked. The chamber was equipped with a Clark-type oxygen sensor, a $\mathrm{pH}$ sensor, and a hydrogen sulfide sensor (Unisense), and the hourly changes in all three parameters were recorded. The stirrer was connected to the decelerating motor and stirred at $9 \mathrm{rpm}$ in the overlying water (Fig. 2). The sediment incubation was performed until the oxygen was completely depleted or the reduction in oxygen became steady. At the beginning and end of the incubation, overlying water was collected, and the DO concentration was adjusted via Winkler titration. The sediment oxygen consumption rate (SOCR) and hydrogen sulfide flux were estimated by reference to the changes in the concentrations measured by the respective sensors in the chamber, and using Equation 1:

$$
F=d C / d t \times V / A
$$

where $F$ is the net flux of substance via the water-sediment boundary layer $\left(\mathrm{mmol} \mathrm{m}^{-2}\right.$ day $\left.^{-1}\right), d C / d t$ is the slope of the changes in the concentration of substance over time (mmol $\left.\mathrm{L}^{-1} \mathrm{~d}^{-1}\right), V$ is the chamber volume $(\mathrm{L})$, and $A$ is the area of the chamber's horizontal plane $\left(\mathrm{m}^{2}\right)$. 


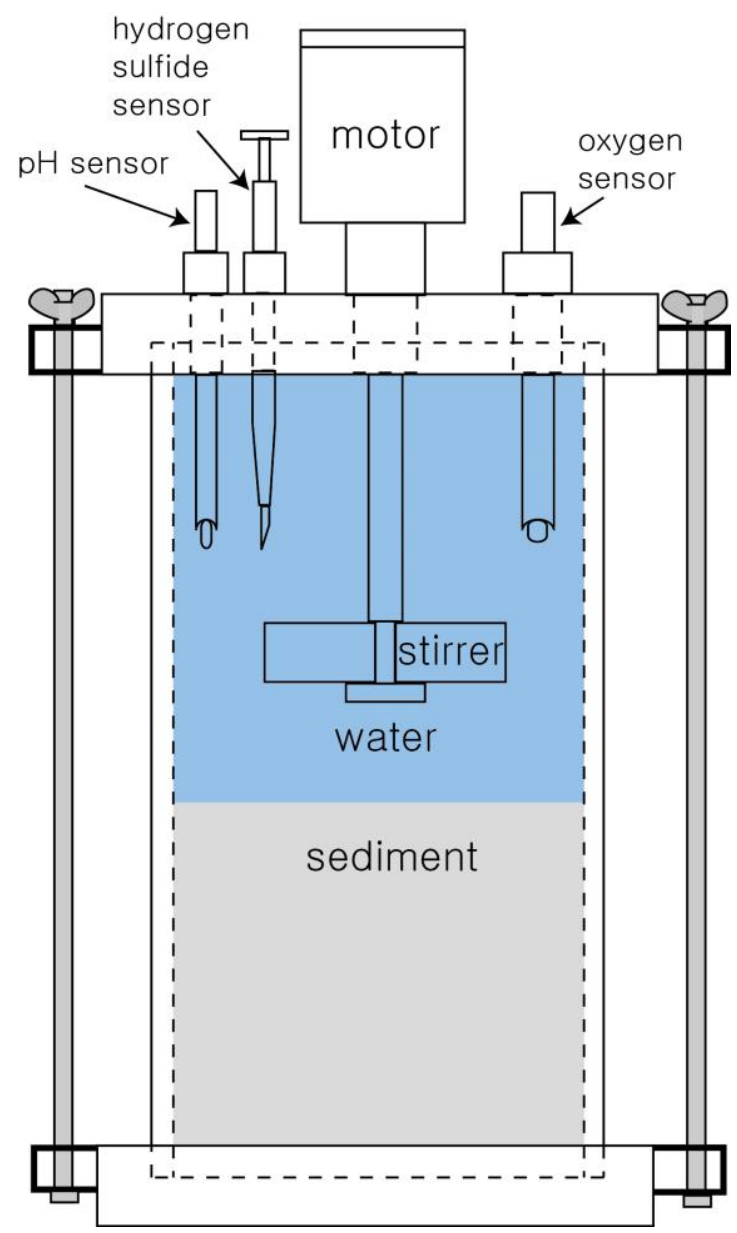

Figure 2. A schematic diagram of a sediment incubation chamber

\section{Results}

\section{Surface sediment distribution}

The surface sediment in the GB is mostly mud, and the amount of sandy sediment increases as one moves toward the southern outer bay. Some gravel sediment is distributed in the deep waterways in the southern outer bay (Fig. 3a). The mean particle size of the sediments tends to be fine in the northern inner bay, becoming coarser toward the outer bay. However, the overall bay contains fine sediment with a particle size above $8 \phi$, except at the entrance to the open sea (Fig. 3b). The surface layer sediment TOC content is high in the inner bay, at $>2 \%$. In the middle of the bay, the TOC content is $<1 \%$ (Fig. 3 c). The $\mathrm{C} / \mathrm{N}$ ratio is $>8$ in several regions that are adjacent to cities in the northern inner bay. However, the overall bay has a low $\mathrm{C} / \mathrm{N}$ ratio of $<8$ (Fig. 3d).

\section{Core sediment vertical distribution}

The TOC content was the highest at site $\mathrm{P} 1$, at $>1.5 \%$ of the sediment surface, with a gradually decreasing trend as the depth increases. However, at sites P2, P3, and P4, there was almost no change in organic carbon content according to depth, and the TOC was relatively low, at $<1 \%$ (Fig. 4). The $\mathrm{CaCO}_{3}$ content showed an unusual distribution 
at site $\mathrm{P} 1$, with $>1 \% \mathrm{CaCO}_{3}$ in the surface sediment, but a very low content of $<0.1 \%$ below $20 \mathrm{~cm}$ in depth. Conversely, at sites $\mathrm{P} 2, \mathrm{P} 3$, and $\mathrm{P} 4$, the $\mathrm{CaCO}_{3}$ content showed almost no vertical change and was fixed at $\sim 2 \%$. At a depth of $\sim 200 \mathrm{~cm}$ at site P4, the $\mathrm{CaCO}_{3}$ content was relatively high, at $4 \%$.
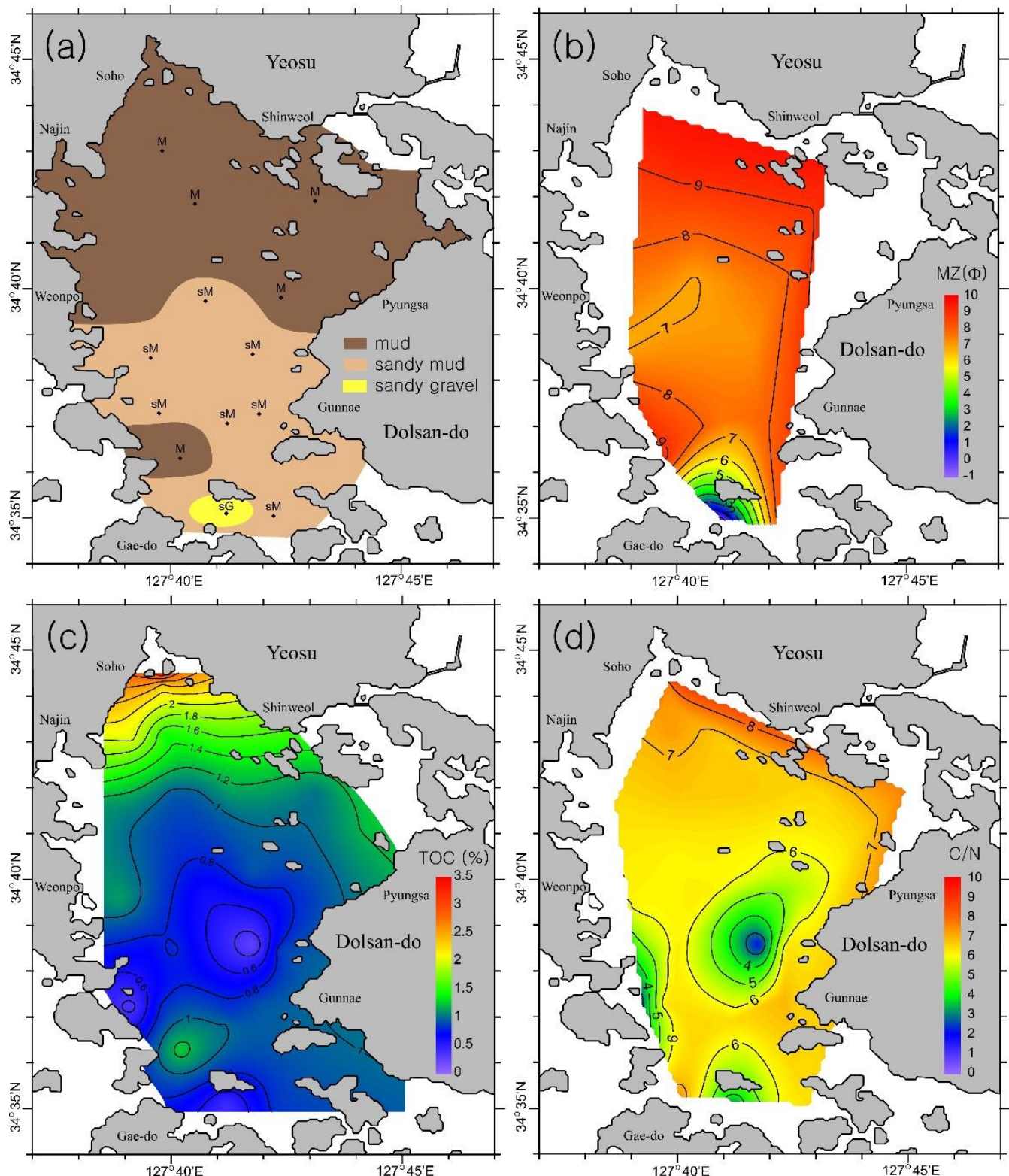

Figure 3. (a) Sediment type, (b) mean grain size, (c) total organic carbon (TOC) content, and (d) $\mathrm{C} / \mathrm{N}$ ratio in surface sediments of Gamak Bay

\section{Sediment oxygen consumption rate (SOCR)}

In the sediments collected from sites C3 and C17 in May 2010, the DO concentration began to decrease as soon as the incubation experiment was started in the chamber, and the decrease was more rapid in the sediment from site $\mathrm{C} 17$ than in that from site $\mathrm{C} 3$ (Fig. 4). At site C17, there was a rapid decrease from the start of the incubation until $12 \mathrm{~h}$, followed by a gradual decrease. This differed from site $\mathrm{C} 3$, where the decrease 
was gradual from the outset. At site $\mathrm{C} 3$, the SOCR was $3.58 \mathrm{mmol} \mathrm{m}^{-2} \mathrm{~d}^{-1}$; at site $\mathrm{C} 17$, it was $9.25 \mathrm{mmol} \mathrm{m}^{-2} \mathrm{~d}^{-1}$. Regarding the incubation results for May 2011, site C3 showed trends similar to those in 2010, while site C17 showed a smaller reduction in DO at the start of the incubation experiment. However, compared to site C3, the extent of DO reduction was larger; $32 \mathrm{~h}$ after the start of the incubation, the DO was completely depleted and the water became anoxic. The SOCR in May 2011 was $3.98 \mathrm{mmol} \mathrm{m}^{-2} \mathrm{~d}^{-1}$ site at $\mathrm{C} 3$ and $7.17 \mathrm{mmol} \mathrm{m}^{-2} \mathrm{~d}^{-1}$ at site $\mathrm{C} 17$.

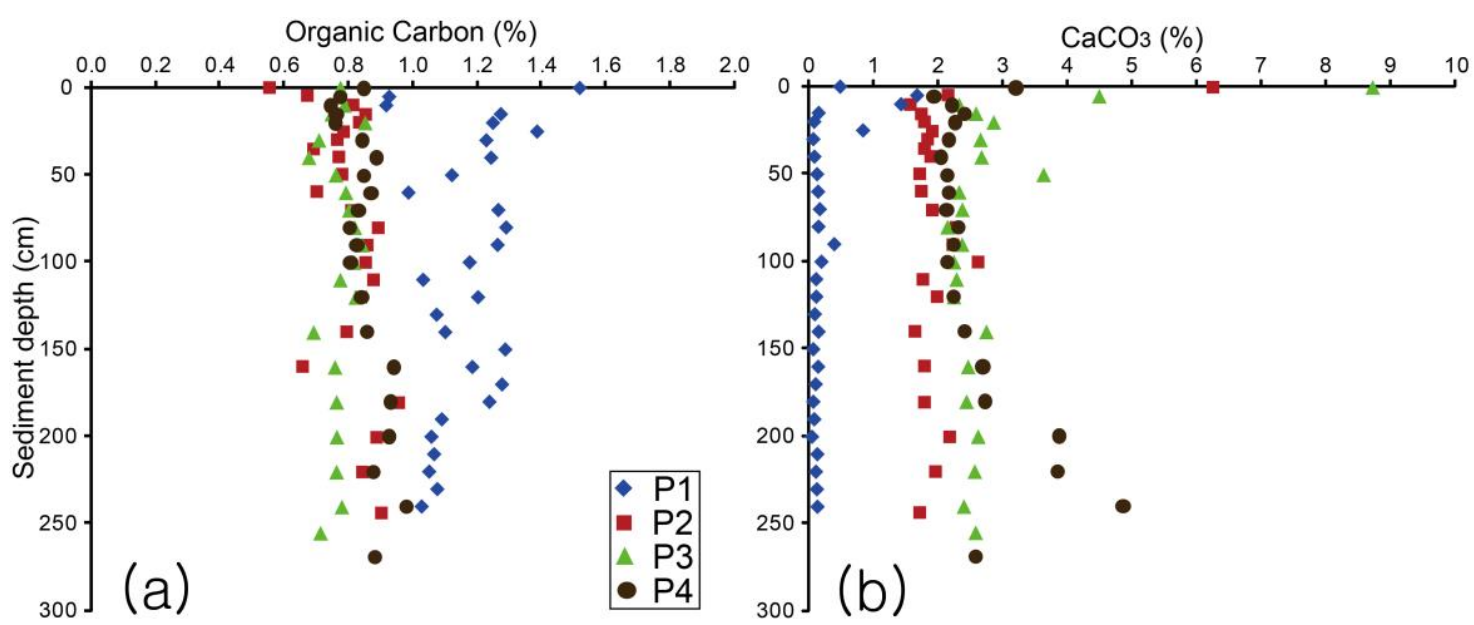

Figure 4. (a) Vertical profiles of organic carbon contents and (b) calcium carbonate $\left(\mathrm{CaCO}_{3}\right)$ contents at four piston coring sites

In the August 2010 sediment incubation experiment, there was no great difference between sites C3 and C17. Site C17 showed a slightly larger reduction in DO, but the reduction trends were almost the same. In contrast, in August 2011, the DO reductions at both sites were more rapid than in 2010. Site $\mathrm{C} 3$ became anoxic at $18 \mathrm{~h}$ after the start of the culture, and site $\mathrm{C} 17$ became anoxic after $28 \mathrm{~h}$ (Fig. 5). In August 2010, the SOCRs were 3.94 and $4.31 \mathrm{mmol} \mathrm{m}^{-2} \mathrm{~d}^{-1}$ at sites C3 and C17, respectively; in August 2011, the SOCRs were 12.43 and $8.18 \mathrm{mmol} \mathrm{m}^{-2} \mathrm{~d}^{-1}$, respectively.

In the November 2010 sediment incubation experiment, the DO decreased more rapidly than in August. The DO concentration in the bottom water was higher in November than in August, and the DO consumption was accelerated. The SOCR at site C17 remained high. Conversely, in 2011, the SOCR at site C17 was markedly lower than at site C3 (Fig. 6). The bottom water temperature in the GB in November 2011 remained comparatively high at $18{ }^{\circ} \mathrm{C}$, and the DO consumption was accelerated by the high water temperature. In November 2010, the SOCRs at sites C3 and C17 were 5.35 and $6.21 \mathrm{mmol} \mathrm{m}^{-2} \mathrm{~d}^{-1}$, respectively; in November 2011, the SOCRs were 6.40 and $3.28 \mathrm{mmol} \mathrm{m}^{-2} \mathrm{~d}^{-1}$, respectively.

In the February 2011 sediment incubation experiment, sites C3 and C17 showed similar DO reductions. Despite having the highest DO concentration at the start of incubation, the SOCR was not large (Fig. 6). In February, the SOCRs at sites C3 and $\mathrm{C} 17$ were 4.43 and $4.23 \mathrm{mmol} \mathrm{m}^{-2} \mathrm{~d}^{-1}$. As the sediment was incubated, the $\mathrm{pH}$ decreased in accordance with the reduction in DO concentration. The reduction in $\mathrm{pH}$ showed a similar trend to the oxygen consumption: when the DO decreased rapidly, the $\mathrm{pH}$ also 
decreased rapidly, and when the decrease in DO was gradual, the decrease in $\mathrm{pH}$ was also gradual (Fig. 7).
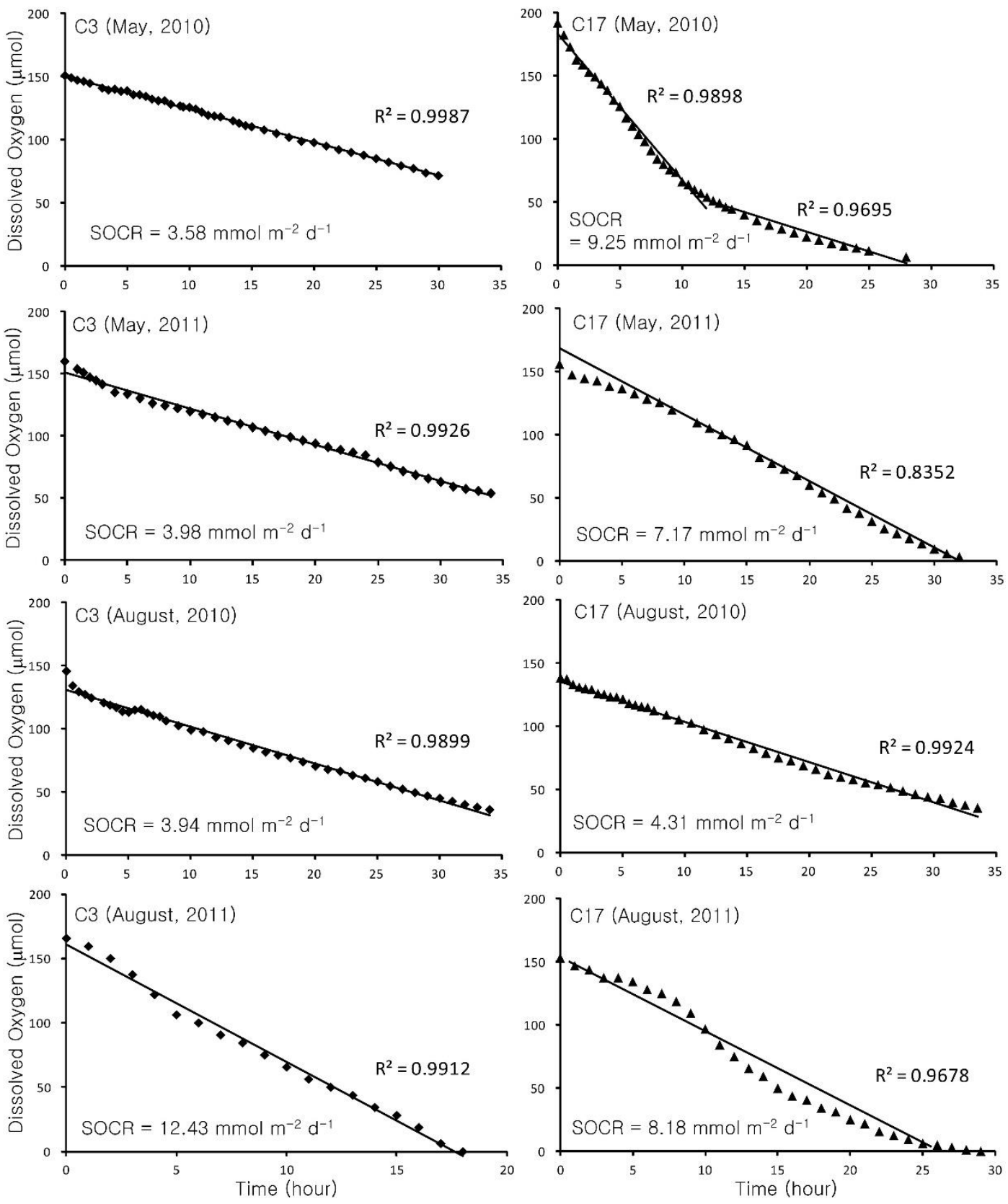

Figure 5. Time-series of bottom water dissolved oxygen $(D O)$ concentrations in chamber experiments using surface sediments from sites C3 and C17 in Gamak Bay, in May 2010, May 2011, August 2010 and August 2011. The solid lines indicate the results of linear regression at considerable oxygen reduced section

\section{Hydrogen sulfide release}

To examine the substances released from sediments under anoxic conditions, a hydrogen sulfide sensor was installed in a sediment culture chamber in August 2011. During the experiment, the maximum oxygen consumption occurred, and the oxygen 
was depleted not long after the start of the culture, creating an anoxic environment. At site C3, hydrogen sulfide was released only a few hours after the DO was depleted. At site $\mathrm{C} 17$, hydrogen sulfide was released $50 \mathrm{~h}$ after the oxygen was depleted (Fig. 8). The hydrogen sulfide flux at the sediment surface layer was $1.38 \mathrm{mmol} \mathrm{m}^{-2} \mathrm{~d}^{-1}$ at site $\mathrm{C} 3$ and $1.31 \mathrm{mmol} \mathrm{m}^{-2} \mathrm{~d}^{-1}$ at site $\mathrm{C} 17$.
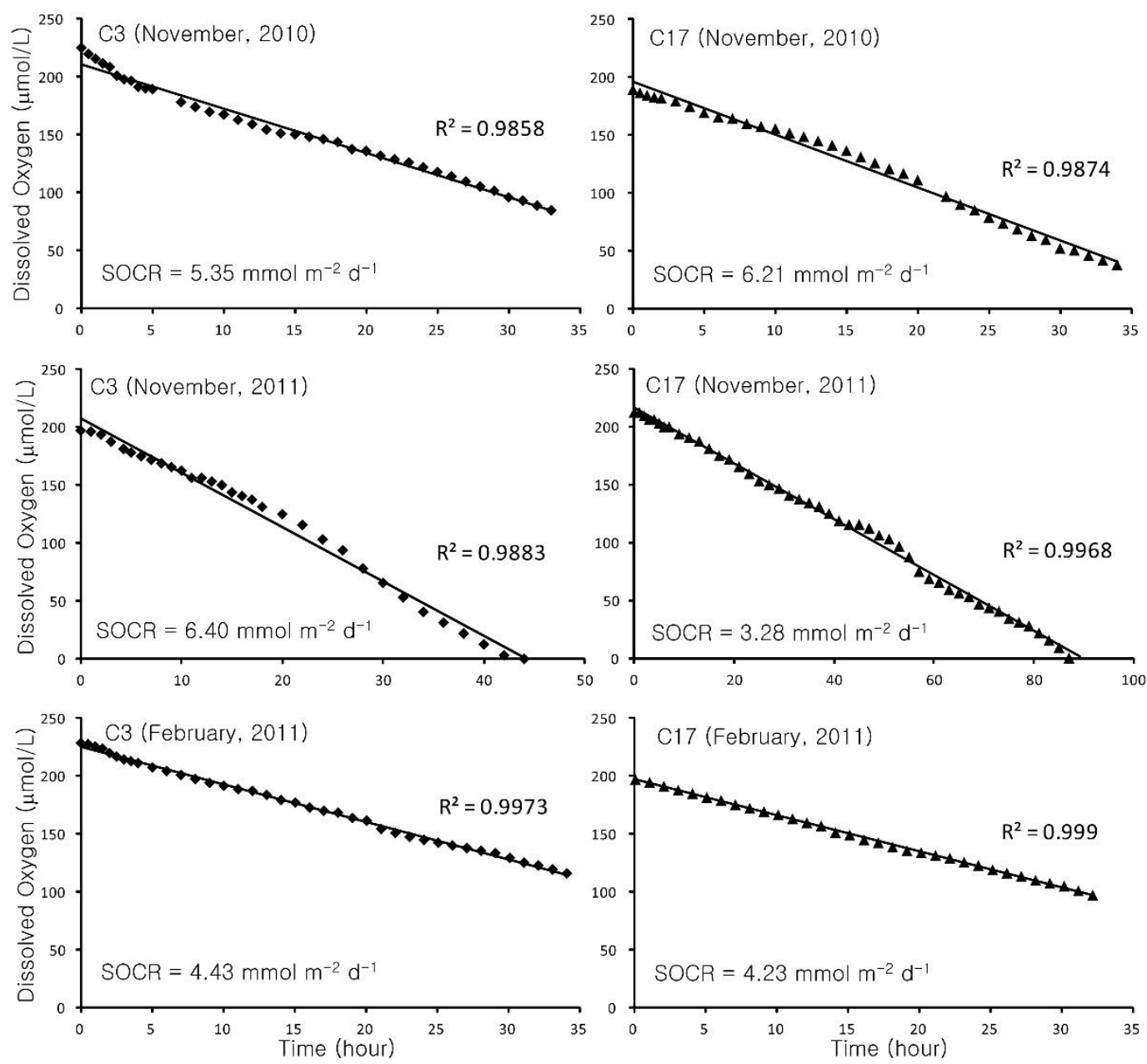

Figure 6. Time-series of bottom water DO concentrations in chamber experiments using surface sediments from sites C3 and C17 in Gamak Bay, in November 2010, November 2011 and February 2011

\section{Discussion}

\section{Characteristics of sediment distribution}

The northern area of the GB is close to a region with a dense urban population, and the ocean currents in the area are very slow. The sediment in the area is artificially inflowing organic matter, which immediately sinks and accumulates. The central area of the GB has a low organic carbon content due to the relatively steady ocean current flow, and deposited organic matter is actively decomposed. As the overall $\mathrm{C} / \mathrm{N}$ ratio in $\mathrm{GB}$ sediment is $<8$, the organic matter deposited in the bay primarily originates from the ocean (Prahl et al., 1994). In the inner area of the GB, some organic matter flows in from the land. 

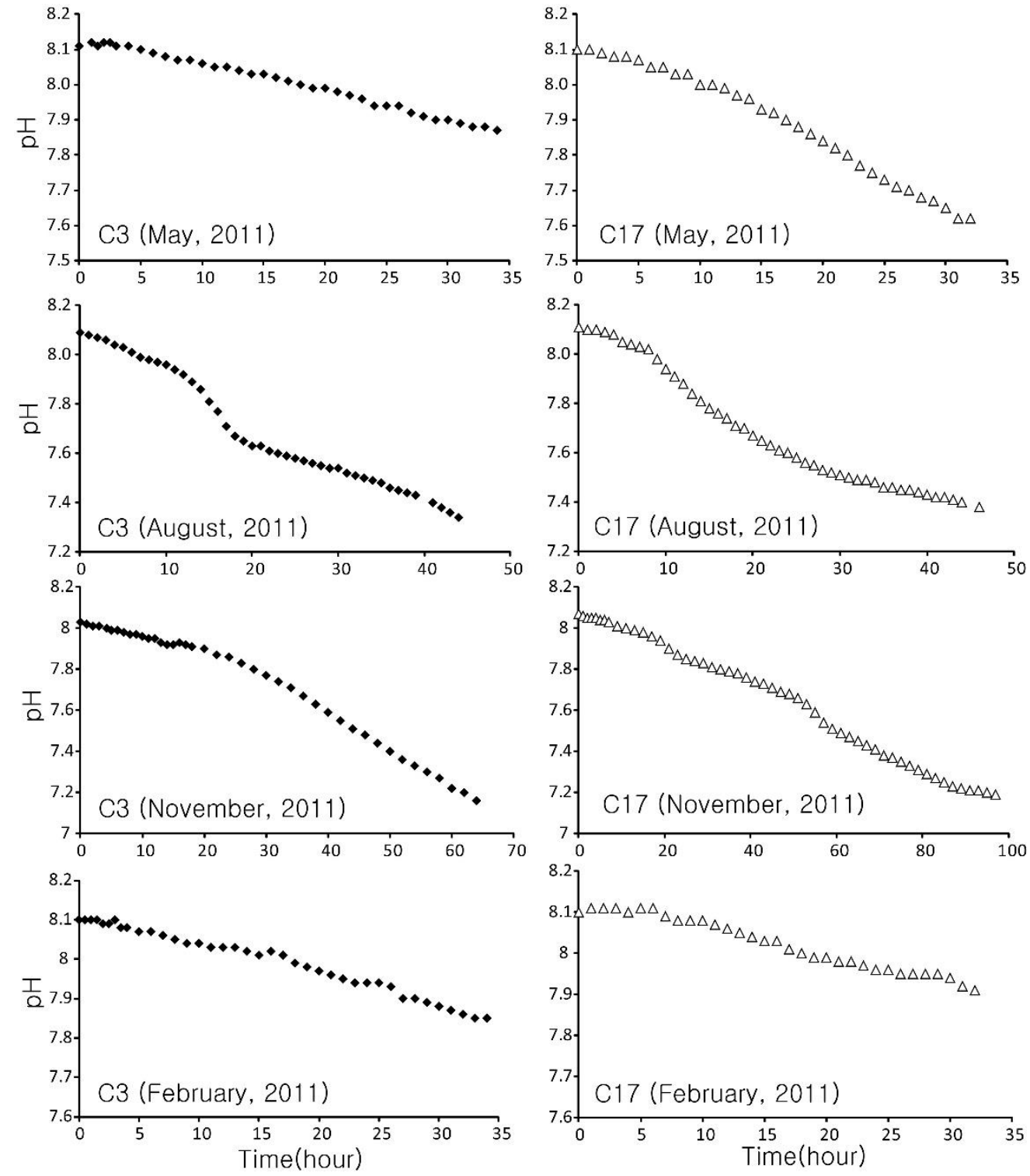

Figure 7. Time-series of bottom water $\mathrm{pH}$ in chamber experiments using surface sediments from sites C3 and C17 in Gamak Bay, in May, August, November, and February 2011
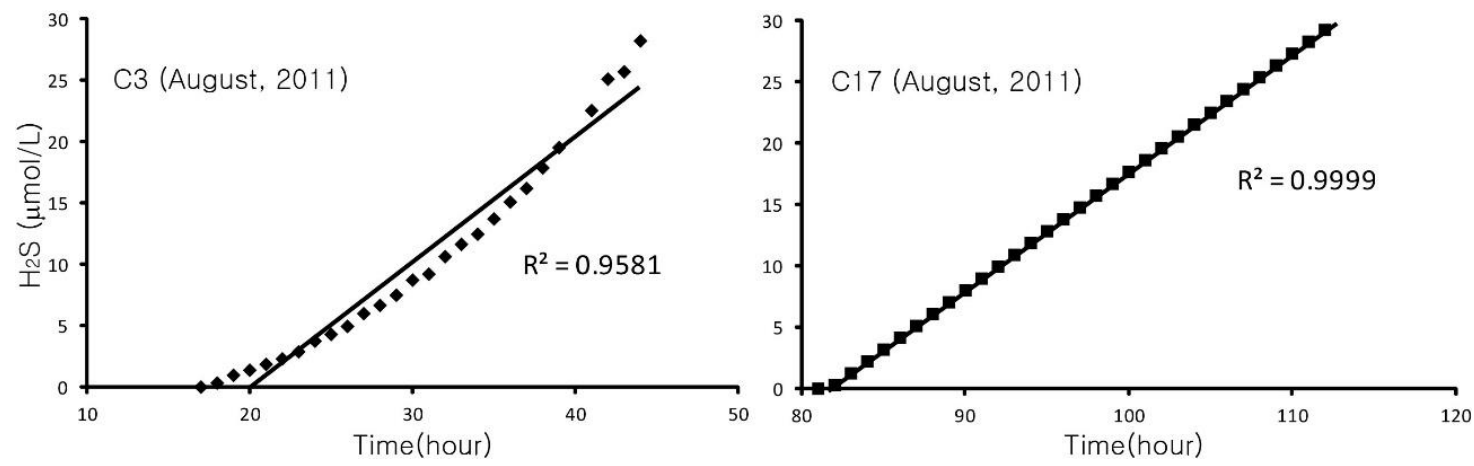

Figure 8. Time-series of bottom water hydrogen sulfide concentrations in chamber experiments using surface sediments from sites C3 and C17 in Gamak Bay, in August 2011 
The surface layer sediments around site P1 had a relatively high organic carbon content distribution compared to the other sites, which corresponds with the core sediment analysis. The organic carbon content was high at the surface, and decreased with depth. This is due to the remineralization process caused by the decomposition of organic matter. However, at other sites, there was almost no change in organic carbon content with sediment depth, due to the relatively low level of organic matter remineralization. Due to the small proportion of organic matter that sinks to the bottom, relatively little remineralization of organic matter occurs.

At site $\mathrm{P} 1$, the vertical distribution of $\mathrm{CaCO}_{3}$ exhibited relatively high contents at the sediment surface, but very low contents at a level only slightly deeper. The surface sediments had a relatively low $\mathrm{CaCO}_{3}$ content compared to the other sites, but the contents further decreased with depth due to dissolution within the sediment. The vertical distribution suggests an environment in which $\mathrm{CaCO}_{3}$ easily dissolves. When the $\mathrm{pH}$ is low, the $\mathrm{CaCO}_{3}$ dissolution rate tends to increase, and it can be inferred that site $\mathrm{P} 1$ had a very low $\mathrm{pH}$ for some time; such low $\mathrm{pH}$ mainly occurs in hypoxic or anoxic environments. Deoxygenation can result in hypoxia (oxygen depletion detrimental to many organisms), and the combined processes are often referred to as ocean acidification and hypoxia (Klinger et al., 2017). The calcification process of marine organisms has mostly exhibited negative sensitivity to ocean acidification, which would lead to a decrease in larval supply and recruitment of adult population (Hendriks et al., 2010; Waldbusser et al., 2015). Ocean acidification can have a significant impact on oyster production in GB, where a large number of oyster farms are well developed.

According to Shin et al. (2012), the sedimentation rate in the central area of the GB is estimated at $2.5 \mathrm{~cm}$ year $^{-1}$, while that in the bay interior is estimated to be slightly lower. Based on this, sediments at the $250 \mathrm{~cm}$ depth are estimated to be 100 years old, and hypoxia may have occurred in the vicinity of site P1 for the past 100 years. This hypoxia is likely the result of the topography of the seabed, which is convex and basinlike in shape.

\section{Sediment oxygen consumption and hydrogen sulfide release}

The larger SOCR at site C17 compared to site C3 is due to numerous benthic organisms, such as bivalves, living in the sediment, where their respiration rapidly reduces the DO. There are relatively fewer benthic organisms living at site $\mathrm{C} 3$, and most of the DO is likely consumed by the chemical decomposition of organic matter and the oxidation of chemical species caused by early diagenesis. Similarly, the SOCR is higher at site $\mathrm{C} 17$, but hypoxia does not occur due to the relatively active seawater flow between the open sea and the southern outer bay (Lee and Chang, 1982), which provides a steady supply of DO.

The release of carbon dioxide during organic matter decomposition causes the bottom water carbon dioxide concentration to increase and the $\mathrm{pH}$ to decrease. The resulting formation of hypoxic water masses contributes to ocean acidification, and the lower $\mathrm{pH}$ can affect organisms directly and indirectly. In particular, the increased solubility of $\mathrm{CaCO}_{3}$ affects both the $\mathrm{CaCO}_{3}$ content in the sediment and the sedimentdwelling organisms, the bodies of which contain $\mathrm{CaCO}_{3}$.

The incubation experiments showed similar SOCRs at sites C3 and C17. However, hypoxic water masses form at site $\mathrm{C} 3$, but not at site $\mathrm{C} 17$, likely due to the action of bottom layer currents. Stratification exists at site C3, and the flow of bottom water is 
completely blocked, while the inflow and outflow of water from the open sea is relatively active at site C17 (KORDI, 2012). The concave basin-shaped seabed topography at site $\mathrm{C} 3$ is likely also a contributing factor.

Anthropogenic processes during the last century (e.g., nutrient and organic matter loading) have caused large increases in the number of areas suffering from hypoxia in the world's coastal oceans (Breitburg et al., 2018; Yoann et al., 2018). Global warming as a causes of oxygen loss in the global ocean (Brewer and Peltzer, 2016). Ocean warming reduces the solubility of oxygen and decreasing solubility is estimated to account for $\sim 15 \%$ of current total global oxygen loss (Helm et al., 2011; Schmidtko et al., 2017).

Kim et al. (2010) examined the river pollution load that flows into the GB. The total monthly flux of the rivers was 87,220-191,686 $\mathrm{m}^{3}$ day $^{-1}$, with a total nitrogen load of $1,112 \mathrm{~kg} \mathrm{day}^{-1}$, a total phosphorus load of $89 \mathrm{~kg} \mathrm{day}^{-1}$, and a TOC load of $285 \mathrm{~kg} \mathrm{day}^{-1}$. Higher pollution loads were seen in May and July when there was a lot of seasonal rain, as well as at the sewage treatment plant near point $\mathrm{C} 3$ and the drainage area near Seonso. It can be inferred that the pollution sources flowing in via rivers directly affect the formation of hypoxic water masses in the northern inner bay. Environmental restoration is greatly affected by the nature of the substances polluting the environment (Gray et al., 2002; Pereira et al., 2004). In the case of organic pollution, the environment recovers relatively slowly from substances with slow, complex decomposition processes, such as sewage, in comparison to the recovery from pollution caused by feed and primary production (Munari, 2003; Smith and Shackley, 2006). In the northern inner bay, excessive organic matter has accumulated due to human activity (Yoon et al., 2008). Therefore, the recovery will likely be very slow, and hypoxia will occur yearly. The SOCR is high when the bottom layer DO concentration is low and the bottom layer temperature is high (Fig. 9). Hypoxic water masses mainly occur during summer in the GB, because the SOCR increases due to high temperatures and the oxygen supply is interrupted by the formation of stratification. Hypoxic water masses in the GB onset in May and continue into November. The chamber experiments demonstrated the possibility of formation of an anoxic environment if the hypoxic water mass continues for a long time, depleting the oxygen in the bottom layer. If the bottom layer becomes anoxic, the $\mathrm{pH}$ might rapidly decrease, causing the release of nutrients and gaseous components, such as hydrogen sulfide, into the sediment.

Kim et al. (2011) estimated that over $70 \%$ of the phosphorous in the GB is labile, and can easily move into the water column due to environmental changes such as sediment disturbances or oxidation/reduction, thus becoming a large source of dissolved phosphorous in the water. Deoxygenation of the sediment increases the possibility of a large release of dissolved phosphorous into the water column. In an anoxic environment, hydrogen sulfide and methane would also be released into the water column.

In the chamber experiments conducted in this study, the hydrogen sulfide concentration in the overlying water was $\sim 30 \mu \mathrm{mol} \mathrm{L} \mathrm{L}^{-1}$, a level that is harmful to organisms. Hydrogen sulfide concentrations of $20-30 \mu \mathrm{mol} \mathrm{L} \mathrm{L}^{-1}$ cause liver damage and fatal gill necrosis in fish (Keimer et al., 1995). Hydrogen sulfide released from anoxic sediments is immediately oxidized by oxygen in the water column (Brooks and Mahnken, 2003). However, even at concentrations $<10 \mu \mathrm{mol} \mathrm{L}^{-1}$, fish experience physiological stress and stunted growth (Black et al., 1995). Long-term anoxic conditions increase the risk that hydrogen sulfide concentrations will rise to levels fatal 
to bay organisms. To date, there have been no reports of organism deaths due to hydrogen sulfide in the GB. However, there have been cases in which hypoxia occurred in July and persisted until October, and the ecosystem may have been disturbed by hydrogen sulfide release. This phenomenon is expected to occur more often in the near future due to global warming.
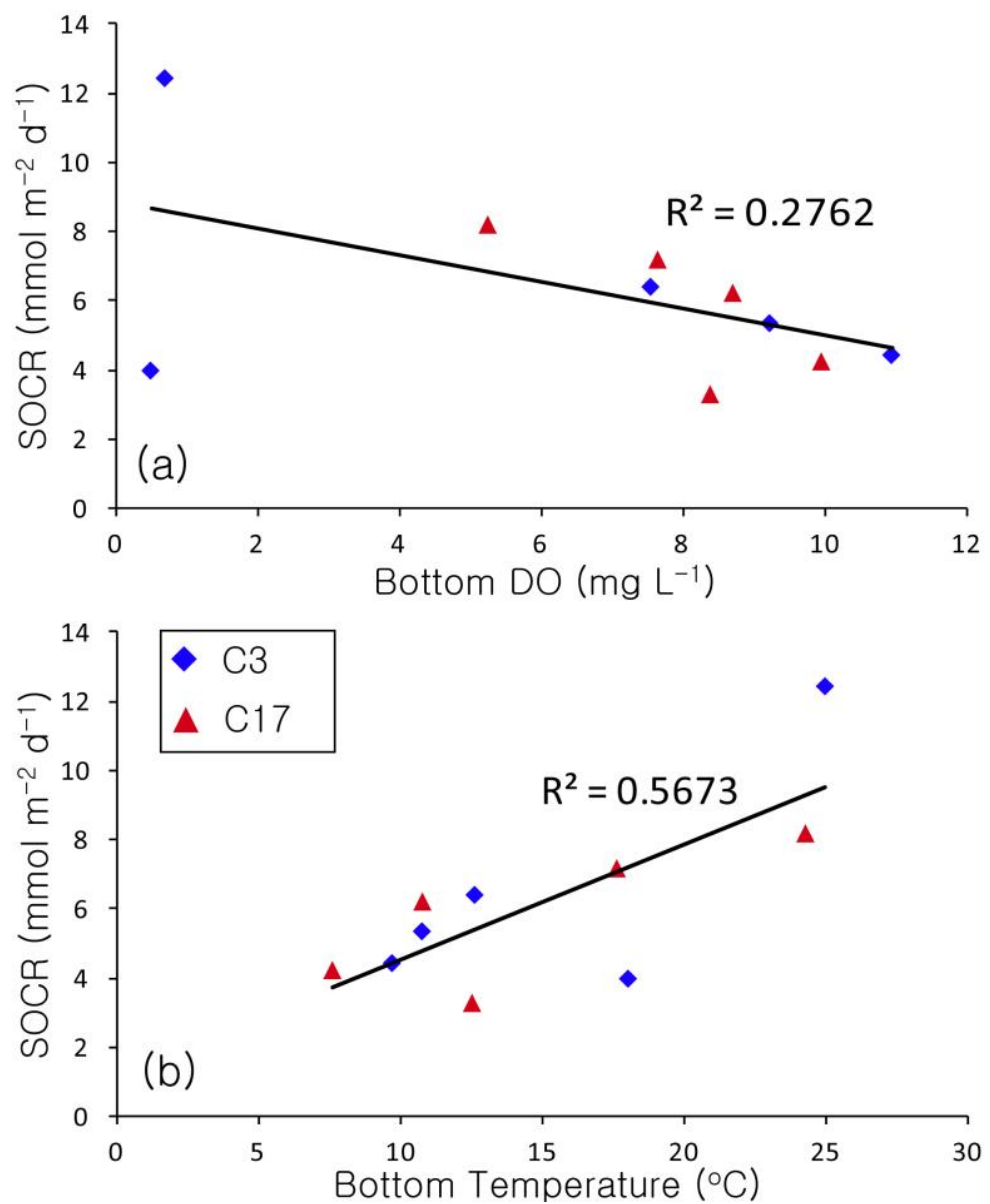

Figure 9. Sediment oxygen consumption rate (SOCR) versus (a) bottom water DO concentration and (b) bottom water temperature at sites C3 and C17 in Gamak Bay

\section{Conclusion}

In the GB, the surface sediment organic matter content is high in the inner bay, and decreases toward the open sea. Most sediment organic matter in the GB originates from the ocean. However, in the northern inner bay, several areas contain sediment organic matter originating from the nearby land. The hypoxic water masses that frequently occur during summer in the northern inner bay are caused by the high sediment organic matter content and obstruction of seawater flow. The core sediment from the northern inner bay exhibited very low $\mathrm{CaCO}_{3}$ contents down to $260 \mathrm{~cm}$ in depth, indicative of a sediment environment with very low $\mathrm{pH}$ in which hypoxia can occur. This recurring hypoxic environment has persisted in these waters for hundreds of years.

At site C3, which is in the northern inner bay and frequently experiences hypoxia, the SOCR ranged from $3.98-12.43 \mathrm{mmol} \mathrm{m}^{-2} \mathrm{~d}^{-1}$, while at site $\mathrm{C} 17$, which is near the open water and does not experience hypoxia, the SOCR ranged from 3.28-8.18 mmol 
$\mathrm{m}^{-2} \mathrm{~d}^{-1}$, which is largely similar. Despite the high SOCR, hypoxia does not occur at the southern part of the GB near the open sea due to the active flow of seawater and the steady supply of oxygen. The SOCR seems to be most closely related to the bottom water temperature. If the temperature is high, the bacteria related to organic matter decomposition are highly active, and when decomposition occurs more actively, more oxygen is consumed.

Hypoxic water masses, which continually occur during summer in the northern inner bay, can cause reductions in $\mathrm{pH}$ and affect ocean acidification. If a hypoxic water mass persists in the bottom layer, the water can become anoxic, and hydrogen sulfide and other chemicals may be released from the sediment. The hydrogen sulfide flux was 1.38 and $1.31 \mathrm{mmol} \mathrm{m}^{-2} \mathrm{~d}^{-1}$ at sites $\mathrm{C} 3$ and $\mathrm{C} 17$, respectively. The chamber experiment results demonstrate the possibility that hydrogen sulfide could be released at a concentration that is harmful to bay organisms.

Acknowledgements. This research was supported by grant from KIOST project (PE99712), titled "Biogeochemical cycling and marine environmental change studies".

\section{REFERENCES}

[1] Black, K. D., Keimer, M. C. B., Ezzi, I. A. (1995): The relationships between hydrodynamics, the concentration of hydrogen sulfide produced by polluted sediments and fish health at several marine cage farms in Scotland and Ireland. - Journal of Applied Ichthyology 12: 10-15.

[2] Breitburg, D., Levin, L. A., Oschlies, A., Grégoire, M., Chavez, F. P., Conley, D. J., Garçon, V., Gilbert, D., Gutiérrez, D., Isensee, K., Jacinto, G. S., Limburg, K. E., Montes, I., Naqvi, S. W. A., Pitcher, G. C., Rabalais, N. N., Roman, M. R., Rose, K. A., Seibel, B. A., Telszewski, M., Yasuhara, M., Zhang, J. (2018): Declining oxygen in the global ocean and coastal waters. - Science 359. https://doi.org/10.1126/science.aam7240.

[3] Brewer, P. G., Peltzer, E. T. (2016): Ocean chemistry, ocean warming, and emerging hypoxia: Commentary. - Journal of Geophysical Research: Oceans 121: 3659-3667.

[4] Brooks, K. M., Mahnken, C. V. M. (2003): Interactions of Atlantic salmon in the Pacific northwest environment II. Organic wastes. - Fishery Research 62: 255-293.

[5] Cho, C. H. (1991): Mariculture and eutrophication in Jinhae Bay, Korea. - Marine Pollution Bulletin 23: 275-279.

[6] Cuevasanta, E., Möller, M.N., Alvarez, B. (2017): Biological chemistry of hydrogen sulfide and persulfides. - Archives of Biochemistry and Biophysics 617: 9-25.

[7] Folk, R. L. (1954): The distribution between grain size and mineral composition in sedimentary rock nomenclature. - Journal of Geology 62: 334-359.

[8] Gray, J. S., Wu, R. S., Or, Y. Y. (2002): Effects of hypoxia and organic enrichment on the coastal marine environment. - Marine Ecology Progress Series 238: 249-279.

[9] Guidotti, T. L. (1994): Occupational exposure to hydrogen sulfide in the sour gas industry: Some unresolved issues. - International Archives of Occupational and Environmental Health 66(3): 153-160.

[10] Hanazato, T. (1997): Development of low-oxygen layer in lake and its effect on zooplankton communities. - Korean Journal of Limnology 30: 246-256.

[11] Helm, K. P., Bindoff, N. L., Church, J. A. (2011): Observed decreases in oxygen content of global ocean. - Geophysical Research Letters 38: L23602. DOI: 10.1029/2011GL049513. 
[12] Hendriks, I. E., Duarte, C. M., Alvarez, M. (2010): Vulnerability of marine biodiversity to ocean acidification: A meta-analysis. - Estuarine Coastal and Shelf Science 86: 157164.

[13] Hong, J. S. (1987): Summer oxygen deficiency and benthic biomass in the Chinhae Bay system, Korea. - Journal of the Korean Society Oceanography 22: 246-256.

[14] Jeng, W. L., Han, B. C. (1996): Coprostanol in a sediment core from the anoxic Tan-Shui Estuary, Taiwan. - Estuarine Coastal and Shelf Science 42: 727-735.

[15] Karim, M. R., Sekine, M., Ukita, M. (2002): Simulation of eutrophication and associated occurrence of hypoxia and anoxic condition in a coastal bay in Japan. - Marine Pollution Bulletin 45: 280-285.

[16] Keimer, M. C. B., Black, K. D., Lussot, D., Bullock, A. M., Ezzi, I. A. (1995): The effects of chronic and acute exposure to hydrogen sulfide on Atlantic salmon (salmo solar L.). - Aquaculture 135: 311-327.

[17] Kim, D. W., Cho, G. O., Yu, J. H., Lee, W. C., Cho, H. S. (2010): Monthly variations of riverine pollutant loading to Gamak Bay. - Proceedings of KOSOMES Biannual Meeting.

[18] Kim, H. G. (1990): Characteristics of flagellate red tide and environmental conditions in Masan Bay. - Bulletin of National Fisheries Research and Development Agency 43: 140.

[19] Kim, S. R., Lee, G. S., Choi, D. L., Kim, D. C., Lee, T., Seo, Y. K. (2014): Development of the holocene sediments in Gamak Bay of the South Sea, Korea. - Journal of the Korean Society Oceanography 19(2): 131-146.

[20] Kim, S. Y., Jun, S. H., Lee, Y. S., Lee, Y. H., Kim, B. M. (2011): Characteristics of phosphate flux at the sediment-water interface in Gamak Bay during the hypoxic water mass. - Journal of Environmental Science 20(9): 1069-1078.

[21] Klinger, T., Chornesky, E. A., Whiteman, E. A., Chan, F., Largier, J. L., Wakefield, W. W. (2017): Using integrated ecosystem-level management to address intensifying ocean acidification and hypoxia in the Califonia Current large marine ecosystem. - Elementa Science of the Anthropocene 5: 16. https://doi.org/10.1525/elementa.198.

[22] KORDI (2012): Ecological Responses in the Hypoxic Condition in Southern Coast of Korea for Ecosystem Management. - Korea Oceanography Research \& Development Institute, Seoul.

[23] Milby, T. H., Baselt, R. C. (1999): Hydrogen sulfide poisoning: clarification of some controversial issues. - American Journal of Industrial Medicine 35: 192-195.

[24] Munari, C., Modugno, S., Ghion, F., Castaldelli, G., Fano, E. A., Rossi, R., Mistri, M. (2003): Recovery of the macrobenthic community in the Valli di Comacchio, northern Adriatic Sea, Italy. - Oceanologica Acta 26: 67-75.

[25] Lee, K. H., Cho, K. D. (1990): Distribution of water temperature and salinity in Gamak Bay. - Korean Journal of Fisheries Aquatic Science 23: 25-39.

[26] Lee, M. C., Chang, S. D. (1982): Tidal exchange of sea water in Gamag Bay. - Journal of the Korean Society Oceanography 17: 12-18.

[27] Lee, T., Hyun, J. H., Mok, J. S., Kim, D. (2008): Organic carbon accumulation and sulfate reduction rates in slope and basin sediments of the Ulleung Basin, East/Japan Sea. - Geo-Marine Letters 28(2): 153-159.

[28] Lee, T., Kim, D., Khim, B. K., Choi, D. L. (2010): Organic carbon cycling in the Ulleung Basin sediments, East Sea. - Ocean and Polar Research 32(2): 145-156.

[29] Lim, H. S., Diaz, R. J., Hong, J. S., Schaffner, L. C. (2006): Hypoxia and benthic community recovery in Korean coastal waters. - Marine Pollution Bulletin 52: 15171526.

[30] Pereira, P. M. F., Black, K. D., McLusky, D. S., Nickell, T. D. (2004): Recovery of sediments after cessation of marine fish farm production. - Aquaculture 235: 315-330. 
[31] Prahl, F. G., Ertel, J. R., Goni, M. A., Sparrow, M. A., Eversmeyer, B. (1994): Terrestrial organic-carbon contributions to sediments on the Washington Margin. - Geochimica et Cosmochimica Acta 58(14): 3035-3048.

[32] Severdroup, H. U., Johnson, M. W., Fleming, R. H. (1972): The Oceans. - Prentice-Hall, Inc., Englewood Cliffs, New Jersey.

[33] Schmidtko, S., Stramma, L., Visbeck, M. (2017): Decline in global oceanic oxygen content during the past five decades. - Nature 542: 335-339.

[34] Shin, H. C. (1995): Benthic polychaetous community in Kamak Bay, southern coast of Korea. - Journal of Korean Society Oceanography 30: 250-261.

[35] Shin, H. H., Park, J. S., Kim, Y. O., Baek, S. H., Lim, D., Yoon, Y. H. (2012): Dinoflagellate cyst production and flux in Gamak Bay, Korea: A sediment trap study. Marine Micropaleontology 94: 72-79.

[36] Smith, J., Shackley, S. E. (2006): Effects of the closure of a major sewage outfall on sublittoral, soft sediment benthic communities. - Marine Pollution Bulletin 52: 645-658.

[37] Terner, R. E., Rabalais, N. N., Swenson, E. M., Kasprzak, M., Romaire, T. (2005): Summer hypoxiz, Northern Gulf of Mexico and its prediction from 1978 to 1995. Marine Environmental Research 59: 65-77.

[38] Waldbusser, G. G., Hales, B., Langdon, C. J., Haley, B. A., Schrader, P., Bunner, E. L., Grey, M. W., Miller, C. A., Gimenez, I. (2015): Satiration-state swnsitivity of marine bivalve larvae to ocean acidification. - Nature Climate Change 5: 273-280.

[39] Wu, R. S. S. (1982): Periodic defaunation and recovery in a subtropical epibenthic community, in relation to organic pollution. - Journal of Experimental Marine Biology and Ecology 64: 253-269.

[40] Wu, R. S. S. (2002): Hypoxia: from molecular responses to ecosystem response. - Marine Pollution Bulletin 45: 35-45.

[41] Yoann, T., Jonathan, F, Denis, C., Arturo, A., Gonçalo, M., Laure, P. (2018): Effect of hypoxia on metabolic functions in marine organism: observed patterns and modelling assumptions within the context of dynamic energy budget (DEB) theory. - Journal of Sea Research 143: 231-242. https://doi.org/10.1016/j.seares.2018.05.001.

[42] Yoon, J. S. (1998): A study on the upwelling phenomena of anoxic bottom water (blue tide phenomena) in the coastal areas. - Journal of the Korean Environmental Science Society 7(3): 291-299.

[43] Yoon, S. P., Kim, Y. J., Jung, R. H., Moon, C. H., Hong, S. J., Lee, W. C., Park, J. S. (2008): Benthic environments and macrobenthic polychaete community structure in the winter of 2005-2006 in Gamak Bay, Korea. - Journal of Korean Society Oceanography 13(1): 67-82. 